clinical aspect, while a band of workers, Sir Alan Drury, Dr. P. L. Mollison, Dr. W. d'A. Maycock and Dr. Margaret E. Mackay, review the problems of blood storage, plasma and its substitutes.

Finally, Dr. W. Ritchie Russell discusses head injuries, with an admirable blend of physiology and surgery which is a model of clinical investigation.

Each of these articles is well documented and makes good reading, since a leading principle is kept well to the fore even when information is scanty and apparently contradictory.

The scientific editor, Dr. W. G. Spector, is to be congratulated on the success of his efforts.

V. UDALI

\section{WORKABLE PEAT RESOURCES OF SCOTLAND}

$\mathrm{W}$ ORKABLE deposits of peat, equivalent in value as fuel to twenty years output of coal, or 500 million tons, are estimated to be available in Scotland as the result of a painstaking inquiry carried out by the Scottish Peat Committee, which had been set up in 1949 and reported in 1953*. This accessible reserve occupies a total area of $1,625,000$ acres, covered to a depth of $2 \mathrm{ft}$. of peat, and contains a thousand million tons of solid fuel, some 600 million tons consisting of mosses of which the depth, accessibility and other features make them suitable for utilization. In the associated inquiries into the winning and utilization of the peat, the Committee kept prominently in mind the prospect that ultimately much of the land now under peat might be reclaimed for agriculture or forestry.

In a number of European countries, perhaps more richly blessed by reserves of peat than is Scotland, peat production has been developed on a considerable scale, and mechanical methods of winning fuel have been well advanced. The various methods available were examined by the Committee. Thus, peat produced by automatic plants, with excavators, macerators and spreaders for drying, is likely to be more expensive than coal in Britain unless smaller types of machines can be made to reduce costs substantially.

Hydro-peat - that is, raw peat disintegrated into a slurry by a high-powered water-jet, pumped from the bog to a drying field and cut into blocks-might have some application if a cheap method of removing water could be devised; but the Committee considers that this is not yet practicable. In the production of milled peat a horizontal cut of about $\frac{1}{2}$ in. thickness is made, the machine operating on the same principle as a motor grass-mower. The milled peat, after preliminary drying in situ and harvesting, is taken to a drying and briquetting plant. The product has a net calorific value of 8,000 B.Th.U. per lb., and is relatively dense and transportable. The process requires fairly favourable climatic conditions for drying, and, accordingly, in Scotland the number of harvests might be limited to some $18-20$ in a season. The cost is roughly competitive with coal as delivered to power stations in the north of Scotland.

The technical problem of greatest difficulty is to find an efficient and economical means of reducing the moisture content of peat from upwards of 90 per

* Scottish Home Department. Report of the Scottish Peat Committee. I'p. $66+8$ plates. (London: H.M.S.O., 1954.) 5s. net. cent in the raw state to a level at which it can be burned. Nearly all processes now operating commercially rely on wind and sun to do so. This makes peat production a seasonal operation with expensive seasonal labour. The application of mechanical presses was investigated, but it was found that their suitability has not reached a scale at which their commercial use could be recommended for Scottish conditions. Other processes considered include wetcarbonizing, de-watering by centrifuge and electroosmosis; but they were all found to be less promising than pressure de-watering. There may, however, be scope for developing some other uses of peat in association with a fuel and power plant-for example, the production of moss litter, or the extraction of waxes. Other processes, such as carbonization, hydrogenation and use as a building material, are considered less hopeful.

Perhaps the most interesting and novel feature of these pioneering efforts has been the application of peat firing to the gas turbine used as a power generator. The attractive features of the gas turbine are the greater flexibility in siting, less demand for cooling water, reduced possibility of damage by abrasion from harmful constituents of its low content of ash, and greater possibilities of more efficient use of the potential heat of the fuel. Thus it may be possible to dry a wet fuel like peat from a higher moisture content by the uso of the waste heat available.

The closed-cycle gas turbine has been investigated by the Scotland Hydro-Electric Board. A description is given in the present report of trials with a machine of this type, of some 500 H.P. capacity, in which a flue-gas drier was incorporated to dry peat from a moisture content of $50-55$ per cent to a moisture content of 30 per cent, thus enabling it to operate with milled peat or with any of the accepted methods of peat production involving air-drying.

Another gas turbine, of $750 \mathrm{~kW}$. capacity, operating on the open cycle, has bcen sponsored by the Ministry of Fuel and Power and is already in limited production, and regarded as having reached a stage of proved reliability. A rotary louvre drum drier has been ordered and should give valuable information for application to both the open- and the closed-cycle systems. It is estimated that a small peat-burning closed-cycle gas turbine of $2,000 \mathrm{~kW}$. might produce power at a cost comparable with small diesel stations of similar output, but the cost would be much higher than that of power from large hydro-electric schemes. On the other hand, once a large peat-fired plant can be developed, the Committee considers that important. economies could result which would enable such a plant to produce power at a cost comparable with large coal-fired steam turbines. Since the report was drafted the Hydro-Electric Board and the Central Electricity Authority have agreed, with assistance from the Government Development Fund, to contribute towards the capital cost of establishing a 2,000-kW. peat-burning unit at Altnabreac, Caithness. Meanwhile, investigations are to go ahead on pressure de-watering and other methods of peat production. An open-cycle machine of $750 \mathrm{~kW}$. and a large press ordered by the Ministry of Fuel and Power are to be included in the developments at the same station. Thus Britain has taken the lead in developing solidfuel gas turbines. Further, the peat experiments foreshadowed in the report will be watched with great interest in a number of other countries, particularly Ireland, Sweden and Canada. 
Another and perhaps no less significant feature of the report is the reference to land development following the winning of the peat. The depopulation of the Highlands may be attributed to the existence of barren areas, costly in the maintenance of social services more abundant in other parts of Britain. The conversion of the peat areas to agricultural use and afforestation requires, beyond the winning of the peat, intensive drainage, the cultivation of arable and pastoral soil conditions, and the features necessary for the planting of trees, namely, a suitable subsoil and absence of exposure to wind. Thus the Forestry Commission estimates that planting an area of twenty thousand acres might employ ultimately six hundred persons when the forest is in full production.

Thus may be seen the potentialities of a hitherto neglected site of natural resources as affected by the march of science and engineering.

R. J. SARJANT

\section{CHEMICAL INDUSTRY IN BRITAIN DURING 1953}

$\mathrm{S}^{\mathrm{U}}$ UPPLEMENTING the report on the chemical industry, 1949, published in February 1950, the Association of British Chemical Manufacturers has now issued a "Report on the Chemical Industry, 1953"*, based on replies received to a questionnaire addressed to its members early in 1953. The present report adopts the same definition of chemical industry as was used in the earlier one: "the manufacture of heavy chemicals, industrial gases, fertilisers, dyestuffs, medicinal and other fine chemicals, explosives, plastics and synthetic resins, but not the compounding of chemicals to make such products as paints, insecticides, sheep and cattle dips, and pharmaceutical preparations". On this basis the industry represents about one-third of the activities covered by the definition of chemicals and allied trades used by the Ministry of Labour and National Service for its statistics.

For 1952, returns were received from 234 of the 272 firms that previously reported for 1948 , and these 234 firms employed capital of $\mathfrak{1} 406 \cdot 8$ million, compared with $£ 230.6$ million in 1948 , the capital of the 38 firms which failed to reply totalling less than $£ 6$ million. The total staff employed in the industry increased from 141,817 to 151,349 , the scientific staff rising from 6,176 to 7,406 , or roughly 20 per cent, compared with the forecast of an increase of 40 per cent in respect of chemists, by 1953 , in the earlier report. Employed capital per employee rose from $£ 1,600$ to nearly $£ 2,700$ at the end of 1952 , when the expansion schemes in progress involved a total capital expenditure of $£ 138$ million, with additional schemes awaiting licences or under consideration to the total of $£ 91$ million. The expenditure of $£ 11 \cdot 2$ million on research and development in 1952 approximates closely to the forecast of 32 per cent increase in 1948, but the number employed on research and development only rose by 8 per cent, from 10,100 to 10,914 ; in the same period the number of scientific workers so employed rose from 3,000 to 3,267 . When the additional laboratories and other experimental facilities, for which capital expenditure of $£ 6 \cdot 2$

- Association of British Chemical Manufacturers. Report on the Chemical Industry, 1953 ; a Supplement to the 1949 Report. Pp. 12. million is in hand, are available, recurrent expenditure on research and development will rise to $£ 12.7$ million or almost 50 per cent above that in 1948 .

New products are being added to the industry's selling range at the rate of several hundred every year, and production has increased by 29 per cent in volume, compared with 15 per cent for all manufacturing industries, with an estimated increase in value of 60 per cent. Productivity increased by 21 per cent on a volume basis and 51 per cent on a value basis, these figures being attributed to the increase in employed capital, the increasing use of instrumentation for process control and the application of work study methods. Nevertheless, it has not been possible, nor will it ever be, to eliminate imports ; of the $£ 49.68$ million imported in $1952, £ 9 \cdot 3$ million consisted of potassium compounds and extracts for tanning, for which there is no available indigenous supply of raw materials. Drugs, medicines and medicinal preparations were imported to the amount of $£ 4.54$ million, cellulose acetate to $£ 2 \cdot 38$ million, sodium compounds to $£ 2.97$ million, vinyl resins to $£ 1.19$ million and synthetic organic dyestuffs to $£ 0.88$ million. Exports were raised from $\mathfrak{1 8 8 . 2 5}$ million in 1948 to $£ 151.7$ million in 1952 ( $£ 146$ million in 1953) with indirect exports of chemicals estimated at $£ 60$ million in 1952 , the United States of America ( $£ 11.07$ million) and India ( $£ 10.9$ million) being the largest markets. Exports to all dollar markets rose from $£ 5.62$ million in 1948 to $£ 19.05$ million in 1952.

The difficulties referred to in the earlier report in the execution of the industry's expansion schemes still exist, though they are less serious. It is much easier to obtain the necessary authorization for a new project, and the sulphur position has been eased. The scarcity of scientific and technical staff still hampers the development of the industry and its efforts to increase productivity, and the rising costs of fuel and transport are seriously affecting the competitive position of the chemical industry and other branches of British industry in the export market. The report claims that there is every prospect that the industry will continue to hold its own and expand its exports, more particularly the specialities being developed by research. The industry is also confident of its ability both to meet the new require. ments of Britain's consuming industries, with their changing technologies, and to provide for the changing demands in the overseas markets where industrialization is taking place.

\section{RECENT ADVANCES IN THE CHEMISTRY AND BIOLOGY OF THE PTERIDINES}

\section{SYMPOSIUM IN LONDON}

A SYMPOSIUM sponsored by the Ciba Foundation, the twenty-fifth of its kind, was held in London during March 22-25, bringing together for the second time chemists and biologists working in the pteridine field. The programme of the sym. posium gave equal weight to discussions upon the chemical and upon the biological aspects of pteridine research, the former being held under the chairmanship of Prof. A. Albert, of the Australian National 